\title{
Potential Sources of Resistance for Melon to Nonpersistently Aphid-borne Viruses
}

Juan Antonio Díaz, Estación Experimental "La Mayora”, Consejo Superior de Investigaciones Científicas, 29750 Algarrobo-Costa, Málaga, Spain; Cristina Mallor, Departamento de Protección Vegetal, S. I. A., Diputación General de Aragón, Zaragoza, Spain; Carmen Soria and Rocío Camero, Estación Experimental "La Mayora", Consejo Superior de Investigaciones Científicas, 29750 Algarrobo-Costa, Málaga, Spain; Elisa Garzo and Alberto Fereres, Centro de Ciencias Medioambientales, Consejo Superior de Investigaciones Científicas, Madrid, Spain; José María Alvarez, Departamento de Protección Vegetal, S. I. A., Diputación General de Aragón, Zaragoza, Spain; María Luisa Gómez-Guillamón, Estación Experimental "La Mayora", Consejo Superior de Investigaciones Científicas, 29750 Algarrobo-Costa, Málaga, Spain; Marisol Luis-Arteaga, Departamento de Protección Vegetal, S. I. A., Diputación General de Aragón, Zaragoza, Spain; and Enrique Moriones, Estación Experimental "La Mayora", Consejo Superior de Investigaciones Científicas, 29750 Algarrobo-Costa, Málaga, Spain

\begin{abstract}
Díaz, J. A., Mallor, C., Soria, C., Camero, R., Garzo, E., Fereres, A., Alvarez, J. M., GómezGuillamón, M. L., Luis-Arteaga, M., and Moriones, E. 2003. Potential sources of resistance for melon to nonpersistently aphid-borne viruses. Plant Dis. 87:960-964.

Two hundred and sixty-eight Cucumis melo and wild relative accessions were evaluated for resistance to Cucumber mosaic virus (CMV), Papaya ringspot virus strain W (PRSV-W), Watermelon mosaic virus (WMV), and Zucchini yellow mosaic virus (ZYMV). Symptom development and systemic infection based on double antibody sandwich enzyme-linked immunosorbent assays were monitored. Sources of resistance were scarce. However, a number of them were found among the C. melo accessions tested. Thus, the accession C-189 behaved similarly to PI 161375 and showed resistance to "common" CMV strains although it was infected by a "song" type CMV. For WMV, the accessions C-768 and C-425, although infected, exhibited very mild symptoms, and recovery from infection occurred in some occasions in the former. A similar trait was also found in C-105, although in this case symptoms rarely appear and part of the plants are not infected. In addition, C-105 was highly resistant to virus transmission by Aphis gossypii, similarly to PI 161375. Accessions C-885 and C-769 exhibited resistance to PRSV-W, WMV, and ZYMV; therefore they are potential sources of multiple resistance. Resistance traits were also found in wild relatives that could be exploited when interspecific barriers with $C$. melo can be circumvented.
\end{abstract}

Melon (Cucumis melo) is a vegetable crop that in Spain provides significant annual income either from local consumption or exportation. Thus in 1998, in Spain, melon ranked second by acreage and production and sixth by economic value (27). In the same year, Spain was the fourth melon producer in the world by fruit yield $(980,000 \mathrm{t})$ and seventh by acreage (45,000 ha) (15). Most (75\%) of the melon is cultivated in central and eastern Spain under open-field conditions, and a significant part $(25 \%)$ is grown under plastic greenhouses in the Mediterranean coastal area of southeastern Spain.

Corresponding author: E. Moriones

E-mail: moriones@eelm.csic.es

Current address of C. Soria: Centro de Investigación y Formación Agraria, Junta de Andalucía, 29140 Churriana, Málaga, Spain.

Accepted for publication 19 March 2003.

Publication no. D-2003-0616-01R

(C) 2003 The American Phytopathological Society
Open field melon crops are commonly affected by viruses, most of them transmitted by aphids in a nonpersistent manner (30) such as the cucumovirus (family Bromoviridae, genus Cucumovirus) Cucumber mosaic virus (CMV) and the potyviruses (family Potyviridae, genus Potyvirus) Watermelon mosaic virus (WMV, formerly designated WMV-2), Papaya ringspot virus strain W (PRSV-W), and Zucchini yellow mosaic virus (ZYMV). Single or multiple infections with these viruses are frequent in Spain (26), causing mosaic, vein clearing, vein banding, chlorotic mottles, and/or distortion in the leaves. Virus infections can result in significant yield losses either by flower abortion or by reduction of fruit quality, especially if plants are infected in early growth stages $(1,6)$.

Virus infections caused by nonpersistently transmitted viruses are difficult to prevent by insecticide application (36), which is the most frequent measure used by growers. Therefore, incorporation of genetic resistance in the host plant is a valuable alternative. Melon is a diploid species of African origin that has a large diversification center from the Mediterra- nean Sea to eastern Asia. Commercial melons carrying resistance to CMV and PRSV-W are available (23). However, although resistance to ZYMV $(11,34)$ and to WMV $(17,18)$ have been reported, resistant cultivars are not available commercially.

The objective of this work was to search for novel sources of resistance in C. melo germ plasm collections. Many crop plants contain only a small fraction of the genetic variation present in their wild relatives. Therefore, although attempts to cross $C$. melo with other Cucumis species have failed (5), wild relatives to $C$. melo have been tested because gene transfer strategies $(19,41)$ may allow their exploitation in the future.

\section{MATERIALS AND METHODS}

Plant material and virus isolates. Two hundred and fifty-three $C$. melo accessions were evaluated for resistance to $\mathrm{CMV}$, PRSV-W, WMV, and ZYMV, including wild melons, land races, and traditional cultivars. These genotypes included accessions from germ plasm banks not tested for virus resistance and some control $C$. melo genotypes for which resistance has already been reported. The latter included the improved melon cultivar 'Freeman's' Cucumber from southeast Asia, which possesses resistance to CMV (20); the Indian Plant Introduction (PI) 414723, resistant to several diseases and pests $(23,28)$; the Korean accession PI 161375 (also called Songwhan Charmi), resistant to virus inoculation by Aphis gossypii and to the "common" CMV strains $(21,37)$; and the American breeding line WMR 29, resistant to PRSV-W (7) and to the potyvirus $\mathrm{Mo}$ roccan watermelon mosaic virus (23). Additionally, 15 accessions of wild relatives to $C$. melo were evaluated: 2 accessions of C. anguria var. longipes, 2 accessions of $C$. africanus, 5 accessions of $C$. dipsaceus, and 1 accession of each of the species $C$. ficifolius, C. meeusei, $C$. metuliferus, $C$. myriocarpus, C. prophetarum, and $C$. zeyheri. Accessions were obtained from germ plasm collections maintained at La May- 
ora-C.S.I.C. (139 accessions) and S.I.A.D.G.A. (65 accessions) in Spain, Çukurova University and EARI in Turkey (29 accessions), and IPK-Gatersleben in Germany (35 accessions). The complete list of accessions tested can be obtained from the authors.

Except for PRSV-W, the virus isolates used in this study were obtained by the authors from commercial cucurbit crops in Spain: the CMV isolates of the DTL (isolates M6.2.1 and M373) and ToRS (isolate B20.2) serogroups (13) were originally obtained from melon; the PRSV-W (isolate Z43) (kindly provided by V. Lisa, CNR, Italy) from zucchini squash (Cucurbita pepo); the WMV (isolate M116) from melon; and the two ZYMVs of the pathotype $0(12,22)$ (isolates $\mathrm{C} 16$ and $\mathrm{C} 71$ ) that differ in their aggressiveness in melon (E. Moriones, unpublished) were obtained from zucchini squash. The M730-CMV used in some inoculations was a CMV of the "song" pathotype (24) obtained from melon in Spain. Prior to the test, all the virus isolates except Z43-PRSV-W and M373-CMV were cloned by two local lesion passages on Chenopodium amaranticolor (Ch. quinoa for CMV), one additional local lesion passage on Ch. quinoa, and then propagation on zucchini squash. The purity of all virus isolates was confirmed by host range and enzyme-linked immunosorbent assay (ELISA) (see below). Infectious stocks for each virus were maintained at $4{ }^{\circ} \mathrm{C}$ as lyophilized material obtained from the systemically infected zucchini squash plants.

Mechanical inoculation and evaluation procedure. Plants of each accession were inoculated mechanically by rubbing Carborundum-dusted cotyledons with extracts from $0.1 \mathrm{~g}$ of infected plant material prepared in $2 \mathrm{ml}$ of $30 \mathrm{mM} \mathrm{Na} \mathrm{HPO}_{4}$, $0.2 \%$ (wt/vol) Na-diethyldithiocarbamate. Plants were inoculated at the fully expanded cotyledons growth stage. To ensure efficient virus inoculation, 5 days after the first inoculation, plants were reinoculated also in the cotyledons. The virus propagation host was zucchini squash ('Diamant F1', Seminis Vegetable Seeds Iberica, Almería, Spain) inoculated 15 days earlier at the same growth stage with the stock of the virus (see before). Prior to the test, the purity of infection of virus source plants was confirmed by double antibody sandwich ELISA (DAS-ELISA) (see below). Presence or absence of virus symptoms was recorded for each test plant 30 days after inoculation (DAI). Then, for each accession and virus combination, young newly developed leaves of two symptomatic, all the asymptomatic, and plants with no clear symptoms were tested for the virus inoculated by DAS-ELISA (see below). Each accession from the Spanish germ plasm banks was tested with two CMV isolates (one of each serogroup), the PRSV-W and the WMV isolates, and the two ZYMV isolates. The accessions from the Turkish and German germ plasm banks were tested with M373-CMV, the PRSV$\mathrm{W}$, the WMV, and C16-ZYMV. Ten test plants per accession and virus combination were normally used in the inoculations, including as inoculation control three plants of the C. melo 'PMR 45' (AsgrowSpain, Almería, Spain) or 'Regal' (Syngenta, Almería, Spain), susceptible to every virus isolate used. Those accessions in which more than seven plants tested positive by DAS-ELISA at $30 \mathrm{DAI}$ were considered susceptible, and those in which the 10 plants tested negative were considered resistant. Accessions that rated as resistant were tested at least twice, in different seasons, to confirm their resistance. Accessions in which less than seven plants tested positive were tested at least a second time in a different season and based on this inoculation were classified as susceptible (seven or more plants tested positive) or heterogeneous (less than seven plants tested positive). A number of the resistant and heterogeneous accessions were also tested by aphid-assisted inoculation (see below) to confirm their behavior. Experiments were conducted in an insect-proof glasshouse at approximately $25^{\circ} \mathrm{C}$ day, $18^{\circ} \mathrm{C}$ night, and 16-h day length, with light supplementation when needed.

Aphid inoculation of virus assisted by A. gossypii. A. gossypii was used as vector in transmission assays because it is the most abundant aphid species on melon in Spain (29) and is an efficient vector of the viruses tested here $(8,10,36)$. For each accession tested, plants at expanded cotyledons and one-leaf growth stage were infested with 20 young adult apterae individuals that were given a 2- to 3-min acquisition period on virus source plants after a starvation period of one and a half hours. Aphids were given a 10-min inoculationaccess period on the test plant by placing them on the upper side of a young leaf. Then, plants were fumigated with 'Confidor' (Imidacloprid 20\% wt/vol, Bayer AG, Leverkusen, Germany) at $1.5 \mathrm{ml} /$ liter dilution. Transmission experiments were conducted in a growth chamber at $22^{\circ} \mathrm{C}$ day and $16^{\circ} \mathrm{C}$ night, $70 \% \mathrm{RH}$, and 16 -h photoperiod (radiation level at 400 to $700 \mathrm{~nm}$, $\left.120 \mu \mathrm{E} \mathrm{m}^{-2} \mathrm{~s}^{-1}\right)$. Presence or absence of virus symptoms was recorded $30 \mathrm{DAI}$ in each test plant, and then plants were analyzed by DAS-ELISA as described below. Virus sources were melon ('PMR 45' or 'Regal') plants inoculated 15 days before by A. gossypii transmission from zucchini squash plants inoculated mechanically with either M6-CMV, M730-CMV, Z43-PRSVW, M116-WMV, C16-ZYMV, or C71ZYMV virus stocks (see above). Before infestation of each experiment, the presence of the virus was confirmed in the source plant by DAS-ELISA (see below). Young adult apterae of A. gossypii were obtained from a nonviruliferous colony that was established from a single virginoparous aptera collected on melon at El Ejido (Almería, Spain) in 1998. Aphids were reared on the melon accession ANC42 (La Mayora-C.S.I.C. germ plasm collection) in an insect-proof glasshouse (conditions described above). The melon accessions 'PMR 45' or 'Regal' were included in every experiment as susceptible controls.

DAS-ELISA. DAS-ELISA was performed with polyclonal antisera from Loewe Biochemica GmbH (Otterfing, Germany) according to manufacturer's instructions. IgGs and alkaline phosphatase-conjugated IgGs were used at recommended dilutions. The procedure was carried out in polystyrene plates using $100 \mu \mathrm{l}$ per well of each of the solutions, antigen, IgGs, and alkaline phosphataseconjugated IgGs, and $150 \mu \mathrm{l}$ per well for substrate solution. Briefly, tissue samples $(0.3 \mathrm{~g})$ were extracted in $3 \mathrm{ml}$ ELISA extraction buffer $(8 \mathrm{~g} \mathrm{NaCl}, \quad 0.4 \mathrm{~g}$ $\mathrm{NaH}_{2} \mathrm{PO}_{4} \cdot 2 \mathrm{H}_{2} \mathrm{O}, 2.7$ g $\mathrm{Na}_{2} \mathrm{HPO}_{4} \cdot 12 \mathrm{H}_{2} \mathrm{O}$, $2 \%$ polyvinylpyrrolidone, in 1 liter of distilled $\mathrm{H}_{2} \mathrm{O}, \mathrm{pH} 7.2$ to 7.4). After addition of p-nitrophenyl phosphate substrate (1 $\mathrm{mg} / \mathrm{ml}$ in $10 \%$ diethanolamine, $\mathrm{pH} 9.8$ ) and incubation for $1 \mathrm{~h}$ at room temperature, ELISA reactions were measured spectrophotometrically at $405 \mathrm{~nm}$ using the plate reader Anthos2001 (Anthos Labtec Instruments GmbH, Salburg, Austria). Negative controls consisted of leaf tissue extracts from mock-inoculated plants of each of the accession tested. Positive controls consisted of leaf tissue extracts from C. melo 'PMR 45' plants experimentally infected with the virus tested. Based on preliminary assays, a sample was considered viruspositive if the $A_{405 \mathrm{~nm}}$ value was greater than twice that of the negative control.

\section{RESULTS AND DISCUSSION}

Two hundred and fifty-three $C$. melo accessions representative of various geographical regions trying to cover diverse genetic sources were screened for resistance to CMV, PRSV-W, WMV, and ZYMV. Geographical distribution was as follows: 13 accessions from Africa, 9 accessions from America, 16 accessions from Central Asia, 169 accessions from Europe (11 accessions from Central Europe, 146 from the Iberian Peninsula, and 12 from other southern European regions), 9 accessions from the Far East and India, 33 accessions from the Middle East (31 accessions from Turkey, and 2 accessions from other Middle Eastern regions), and 4 accessions of unknown origin. Special attention was given to Turkey and the Iberian Peninsula sources because they are primary and secondary $C$. melo diversification centers, respectively (14). Results of the inoculations of the selected genotypes are summarized in Table 1. It is important to note that, although $C$. melo genotypes of diverse geographical origin and wild rela- 
tives were tested in this study, resistance traits are almost absent. This agreed with the results obtained by other authors (reviewed in 23 and 31), which emphasize the difficulty of finding sources of natural resistance to nonpersistently aphid-borne viruses causing mosaic in $C$. melo. In our study, complete resistance was only found against PRSV-W in the control C. melo PI 414723 and in the $C$. metuliferus accession tested. However, heterogeneous responses were found in a number of the genotypes analyzed (Table 1). Therefore, potential sources of resistance seemed to be present.

Table 2 compiles the reactions of the genotypes that exhibited the most interesting traits, along with those of the control genotypes. Among these latter genotypes, PI 414723, which exhibited resistance to PRSV-W and heterogeneous responses to both ZYMV isolates, whereas it was susthe best level of resistance was found for

ceptible to WMV and CMV (Table 2). PI 414723 is an interesting source for multiple disease and pest resistance (2), and breeding lines have been derived from it for resistance to WMV (17), PRSV-W (33), and ZYMV (11,34). The accession PI 161375 exhibited resistance to M-373, a common CMV strain. Resistance was also exhibited by PI 161375 to the CMV isolates B20.2 and M6, also of the common type; however, in these cases a heterogeneous response was found and few plants were infected (Table 2), suggesting a variable response depending on the CMV isolate. In fact, complete overcoming of the resistance present in PI 161375 was reported for CMV isolates of the named song pathotype (24). This was confirmed here using the song isolate M730-CMV, which infected all the PI 161375 plants inoculated (Table 2). Also, the resistance of this accession to virus infection when A. gossypii

Table 1. Results of mechanical inoculation of Cucumis melo and wild relative genotypes tested with CMV, PRSV-W, WMV, and ZYMVa

\begin{tabular}{lcccc}
\hline & \multicolumn{3}{c}{ Number of $\boldsymbol{C}$. melo/number of wild relative accessions } \\
\cline { 2 - 5 } Virus tested & Susceptible & Resistant $^{\mathbf{b}}$ & Heterogeneous $^{\mathbf{b}}$ & Total \\
\hline CMV & $198 / 14$ & $0 / 0$ & $4 / 1$ & $202 / 15$ \\
PRSV-W & $186 / 10$ & $1 / 1$ & $9 / 4$ & $196 / 15$ \\
WMV & $182 / 12$ & $0 / 0$ & $8 / 2$ & $190 / 14$ \\
ZYMV & $223 / 14$ & $0 / 0$ & $7 / 1$ & $230 / 15$ \\
\hline
\end{tabular}

${ }^{\mathrm{a}} \mathrm{CMV}$, Cucumber mosaic virus; PRSV-W, Papaya ringspot virus strain $\mathrm{W}$; WMV, Watermelon mosaic virus; ZYMV, Zucchini yellow mosaic virus.

${ }^{\mathrm{b}}$ Only those accessions that showed resistant or heterogeneous response to all isolates tested in this study (excluded M730-CMV) were indicated. Heterogeneous genotypes for CMV are C. melo C189, C-625, 'Freeman's' Cucumber and PI 161375, and C. zeyheri C-277. For PRSV-W, the resistant genotypes are C. melo PI 414723 and $C$. metuliferus $\mathrm{C}-76$, and the heterogeneous $C$. melo C019, C-422, C-435, C-759, C-762, C-769, C-885, C-921, and PI 161375, and C. myriocarpus C073, C. anguria C-279, C. dipsaceus C-594, and C. prophetarum C-633. For WMV, the heterogeneous genotypes are C. melo C-087, C-105, C-127, C-129, C-625, C-641, C-769, and C-885, and C. africanus C-205, and $C$. anguria C-279. For ZYMV, the heterogeneous genotypes are C. melo C-128, C-129, C-625, C-769, C-885, C-899, and PI 414723, and C. africanus C-205. is the vector was confirmed during $A$. gossypii-assisted inoculation experiments. In fact, using this vector, the inoculation of PI 161375 with M730-CMV or C16-ZYMV failed, except in some few cases (Table 2), similarly to what was observed by Lecoq et al. (21) when performing mass inoculation of this genotype with another CMV of the song pathotype. The C. melo 'Freeman's' Cucumber exhibited resistance to the M6$\mathrm{CMV}$ as expected from the results reported for this genotype (20). However, similarly to PI 161375 , the resistance to CMV was isolate-specific, because a heterogeneous response was shown with B20.2-CMV and it was completely overcome by M730CMV (Table 2). The melon WMR 29 was susceptible to every virus tested. This melon was reported to give symptomless resistance when inoculated with several PRSV-W isolates $(7,33)$; however, we observed symptoms when the Z43-PRSV$\mathrm{W}$ isolate was used. Therefore, variation seems to exist in the response of WMR 29 to different PRSV-W isolates, probably related to the diversity already shown to exist between isolates of this virus $(3,4)$.

Except for control lines, none of the $C$. melo accessions screened in this work exhibited complete resistance to any virus tested, although several of them merit some attention because of their observed behavior. The Japanese (C-189) accession exhibited resistance to CMV. However, similarly to 'Freeman's' Cucumber, this genotype was resistant to M6-CMV but showed a heterogeneous response with B20.2-CMV and susceptibility with M730CMV (Table 2), suggesting a similar resistance to CMV in these two genotypes. Accessions C-768 (Piel de Sapo type) and C-425 (Castellanos) are two accessions from Spain that, although completely sus-

Table 2. Reactions of Cucumis melo accessions to mechanical and Aphis gossypii-assisted inoculation with CMV, PRSV-W, WMV, and ZYMV ${ }^{\mathrm{a}}$

\begin{tabular}{|c|c|c|c|c|c|c|c|c|}
\hline \multirow[b]{3}{*}{ Accession } & \multicolumn{8}{|c|}{ Virus isolates } \\
\hline & \multicolumn{4}{|c|}{ CMV isolates } & \multirow{2}{*}{$\begin{array}{c}\text { PRSV-W } \\
\text { Z43 }\end{array}$} & \multirow{2}{*}{$\begin{array}{l}\text { WMV } \\
\text { M116 }\end{array}$} & \multicolumn{2}{|c|}{ ZYMV isolates } \\
\hline & M6 & M373 & B20.2 & M730 & & & C16 & C71 \\
\hline Japanese (C-189) & $0 / 7,0 / 10,0 / 10^{\mathrm{b}}$ & - & $3 / 7,4 / 10,1 / 10$ & $10 / 10$ & $7 / 7$ & $7 / 7$ & $7 / 7$ & $9 / 10$ \\
\hline CUM-474 (C-885) & $-^{\mathrm{c}}$ & 9/9 & - & - & $6 / 10,0 / 5,6 / 8$ & $2 / 10,4 / 10$ & $7 / 10,3 / 8$ & $3 / 10$ \\
\hline \multirow[t]{2}{*}{ Piel de Sapo (C-769) } & - & - & - & - & $\begin{array}{l}5 / 10,11 / 20 \\
1 / 10\end{array}$ & $\begin{array}{l}7 / 10,3 / 20 \\
0 / 10\end{array}$ & $\begin{array}{l}3 / 10,3 / 10 \\
2 / 10\end{array}$ & $\begin{array}{l}0 / 10,8 / 10, \\
1 / 8\end{array}$ \\
\hline & $16 / 16^{\mathrm{d}}$ & & & & $2 / 8,7 / 8$ & $6 / 8,6 / 7$ & & $5 / 14$ \\
\hline \multirow[t]{2}{*}{ TGR-1551 (C-105) } & $5 / 5$ & $7 / 7$ & $5 / 5$ & $5 / 5$ & $10 / 10$ & $\begin{array}{l}8 / 10,14 / 20 \\
8 / 10\end{array}$ & $10 / 10$ & $10 / 10$ \\
\hline & $0 / 10,0 / 10$ & & & & & $0 / 10,0 / 10$ & $0 / 10,0 / 10$ & \\
\hline \multicolumn{9}{|l|}{ Controls } \\
\hline PI 414723 & $7 / 7$ & - & $6 / 6$ & - & $0 / 6,0 / 6,0 / 4$ & $5 / 6,5 / 7$ & $0 / 6,1 / 7,2 / 10$ & $\begin{array}{c}0 / 7,0 / 7 \\
2 / 10\end{array}$ \\
\hline PI 161376 & $\begin{array}{l}0 / 7,2 / 10,0 / 10 \\
0 / 10,0 / 10\end{array}$ & $0 / 10$ & $0 / 7,1 / 10,0 / 10$ & $\begin{array}{l}9 / 9 \\
0 / 10,2 / 10\end{array}$ & $1 / 10,5 / 10,4 / 4$ & $3 / 5$ & $\begin{array}{l}9 / 10 \\
1 / 10\end{array}$ & $10 / 10$ \\
\hline 'Freeman's' Cucumber & $0 / 7,0 / 10,0 / 10$ & - & $1 / 7,0 / 10,1 / 10$ & $10 / 10$ & - & $7 / 7$ & $7 / 7$ & $7 / 7$ \\
\hline WMR 29 & $7 / 7$ & - & $7 / 7$ & - & $7 / 7$ & $7 / 7$ & $3 / 5,10 / 10$ & $7 / 7$ \\
\hline \multirow[t]{2}{*}{ Susceptible controle } & $10 / 10$ & $10 / 10$ & $10 / 10$ & $11 / 11$ & $10 / 10$ & $10 / 10$ & $10 / 10$ & $10 / 10$ \\
\hline & $10 / 10,10 / 10$ & & & $10 / 10,10 / 10$ & $3 / 3,2 / 2$ & $2 / 5,6 / 10$ & $10 / 10,10 / 10$ & $1 / 2$ \\
\hline
\end{tabular}

${ }^{a} \mathrm{CMV}$, Cucumber mosaic virus; $\mathrm{PRSV}-\mathrm{W}$, Papaya ringspot virus strain W; WMV, Watermelon mosaic virus; ZYMV, Zucchini yellow mosaic virus.

${ }^{\mathrm{b}}$ Number of infected plants/total number of plants tested, in repeated experiments.

c - , not tested.

${ }^{\mathrm{d}}$ In italics, results of inoculations made using Aphis gossypii.

e C. melo 'PMR 45' (Asgrow-Spain, Almería, Spain) or C. melo 'Regal' (Syngenta, Almería, Spain). 
ceptible based on virus detection by DAS-ELISA when inoculated with WMV, exhibited very mild symptoms (delayed in C-768). Moreover, in some of the plants of C-768, a recovery from infection was observed. Therefore, these accessions could be potential sources of resistance to WMV infections, but more detailed analysis to evaluate their usefulness is required. Two other accessions, C885 (CUM-474) (from the IPK collection, originally from the United States) and C769 (Piel de Sapo type), exhibited a heterogeneous response when inoculated with either PRSV-W, WMV, or ZYMV (Table 2). The latter accession was also tested by $A$. gossypii inoculation, showing that a heterogeneous response is still exhibited against PRSV-W and C71-ZYMV, whereas this was not evident with WMV and M6-CMV (Table 2). These two accessions are currently under study because they could be potential sources for multiple virus resistance.

Special attention was given to an accession from Zimbabwe, C-105 (TGR-1551). This accession was infected by WMV following mechanical inoculation in some of the plants (Table 2), but infected plants exhibited very mild symptoms or were symptomless. In addition, low virus levels seem to be present in infected plants (J. A. Díaz, M. L. Gómez-Guillamón, and E. Moriones, unpublished). As sources of resistance in C. melo against WMV are scarce $(18,23,31)$, more precise studies have been undertaken to better understand the performance of TGR-1551 against WMV. Interestingly, when A. gossypii was used to inoculate TGR-1551 plants, we found that it was unable to transmit any of the viruses tested (CMV, WMV, and ZYMV), although this accession was susceptible to them when inoculated mechanically (Table 2 ; preliminary results in reference 38 ). This response to $A$. gossypii inoculation resembled that of PI 161375 (21), which was reported to be resistant to virus transmission by $A$. gossypii because of a single dominant gene, Vat (32). The interaction of TGR-1551 with A. gossypii was characterized elsewhere $(16,38)$, and it was found that this accession, in addition to resistance to virus transmission by $A$. gossypii, also exhibited resistance to the aphid itself, showing that aphids exposed to TGR-1551 were unable to settle on the plant and to initiate ingestion from the phloem. It is interesting to note that TGR1551 has also been described as resistant to infection by Cucurbit yellowing stunting disorder virus (genus Crinivirus, family Closteroviridae) (25) and to the natural vector of this virus, the sweet-potato whitefly Bemisia tabaci (Hemiptera: Aleyrodidae) (39). Therefore, the results obtained here emphasized the potential interest of this accession as a donor of multiple disease and pest resistance traits for melon breeding programs.
In addition to $C$. melo genotypes, a number of wild relatives to this species were tested. Among them we found complete resistance to PRSV-W in the C. metuliferus tested (accession C-76) (Table 2). Resistance to PRSV-W in some genotypes of this species has been already reported by Provvidenti and Gonsalves (35). Accessions of other wild relatives exhibited a heterogeneous response to some viruses (Table 1). For example, the $C$. zeyheri tested (accession C-277) was resistant to M6-CMV and showed a heterogeneous response against B20.2-CMV, M373-CMV, and M730-CMV. Similarly, one of the accessions of $C$. anguria var. longipes tested (C-279) exhibited a heterogeneous resistant behavior against WMV and PRSV-W, and one accession of $C$. africanus (C-205) gave heterogeneous responses against WMV and the two ZYMVs tested. Therefore, there are potential resistant traits present in $C$. melo wild relatives. However, exploitation of these traits seems to be difficult at present, as crosses between $C$. melo and wild relatives cannot be achieved $(5,9)$. Thus, the usefulness of the resistance found in wild relatives for melon breeding will largely depend upon the development of gene transfer strategies that circumvent interspecific barriers. In this sense, genetic studies can help to identify the desirable traits of wild species, which would be transferred to commercial varieties by introgression breeding (41). In fact, molecular cloning of resistant genes is now allowing their transfer between distantly related species (for recent review see 19). Also, resistance genes have been demonstrated to function after transfer as transgenes (40).

This study revealed that sources of natural resistance to CMV, PRSV-W, WMV, and ZYMV in $C$. melo are very limited. However, some promising heterogeneous resistance responses were found in a number of $C$. melo accessions which can be potential sources of resistance for melon and are currently under study. Among them, TGR-1551 seems to be a source for multiple resistance. Research is underway in this case to determine the extent, usefulness, genetic control, and basis of the resistance found against WMV.

\section{ACKNOWLEDGMENTS}

This research was supported by grants SC98-046C3-2 (Instituto Nacional de Investigaciones y Tecnología Agrarias, INIA, Spain), 1FD97-0271 (Comisión Interministerial de Ciencia y Tecnología, CICYT, Spain, and European Union), and EU-GENRES-108 (European Union). J. A. Díaz, C. Mallor, and E. Garzo are recipients of fellowships from Ministerio de Ciencia y Tecnología (MCYT), Spain. We wish to thank K. Abak and A. Börner for providing germ plasm from the Çukurova University/EARI and IPK-Gatersleben, respectively, V. Lisa for providing the isolate of PRSV-W, and M. V. Martín for technical assistance.

\section{LITERATURE CITED}

1. Alonso-Prados, J. L., Fraile, A., and GarcíaArenal, F. 1997. Impact of cucumber mosaic virus and watermelon mosaic virus 2 infection on melon production in Central Spain. J. Plant Pathol. 79:131-134.

2. Anagnostou, K., Jahn, M., and Perl-Treves, R. 2000. Inheritance and linkage analysis of resistance to zucchini yellow mosaic virus, watermelon mosaic virus, papaya ringspot virus and powdery mildew in melon. Euphytica 116:265-270.

3. Baker, C. A., Lecoq, H., and Purcifull, D. E. 1991. Serological and biological variability among papaya ringspot virus type-W isolates in Florida. Phytopathology 81:722-728.

4. Bateson, M. F., Lines, R. E., Revill, P., Chaleeprom, W., Ha, C. V., Gibbs, A. J., and Dale, J. L. 2002. On the evolution and molecular epidemiology of the potyvirus Papaya ringspot virus. J. Gen. Virol. 83:2575-2585.

5. Beharav, A., and Cohen, Y. 1995. Attempts to overcome the barrier of interspecific hybridization between Cucumis melo and C. metuliferus. Isr. J. Plant Sci. 43:113-123.

6. Blua, M. J., and Perring, T. M. 1989. Effect of zucchini yellow mosaic virus on development and yield of cantaloupe (Cucumis melo). Plant Dis. 73:317-320.

7. Bohn, G. W., Kishaba, A. N., and McCreight, J. D. 1980. WMR 29 muskmelon breeding line. HortScience 15:539-540.

8. Castle, S. J., Perring, T. M., Farrar, C. A., and Kishaba, A. N. 1992. Field and laboratory transmission of watermelon mosaic virus 2 and zucchini yellow mosaic virus by various aphid species. Phytopathology 82:235-240.

9. Chatterji, M., and More, T. A. 1991. Techniques to overcome barrier of interspecific hybridization in Cucumis. Cucurbit Genet. Coop. Rep. 14:66-68.

10. Coudriet, D. L. 1962. Efficiency of various insects as vectors of cucumber mosaic and watermelon mosaic viruses in cantaloups. $\mathrm{J}$. Econ. Entomol. 55:519-520.

11. Danin-Poleg, D., Tzuri, G., Reis, N., Karchi, Z., and Katzir, N. 2000. Search for molecular markers associated with resistance to viruses in melon. Proceedings Cucurbitaceae 2000. M. Katzir and H. S. Paris, eds. Acta Hortic. (ISHS 2000) 510:399-403.

12. Desbiez, C., and Lecoq, H. 1997. Zucchini yellow mosaic virus. Plant Pathol. 46:809829.

13. Devergne, J. C., and Cardin, L. 1973. Contribution a l'etude du virus de la mosaïque du cocombre (CMV). IV. Essai de classification de plusieurs isolats sur la base de leur structure antigenique. Ann. Phytopathol. 5:409430.

14. Esquinas-Alcázar, J. T., and Gulick, P. J. 1983. Genetics resources of Cucurbitaceae. International Plant Genetic Resources Institute, FAO, Rome.

15. FAO. 1998. FAO Production Yearbook, Vol 52. FAO Statistics Series No. 135. Food and Agriculture Organization of the United Nations, Rome.

16. Garzo, E., Soria, C., Gómez-Guillamón, M L., and Fereres, A. 2002. Feeding behavior of Aphis gossypii on resistant accessions of different melon genotypes (Cucumis melo). Phytoparasitica 30:129-140.

17. Gilbert, R. Z., Kyle, M. M., Munger, H. M., and Gray, S. M. 1994. Inheritance of resistance to Watermelon mosaic-virus in Cucumis melo L. HortScience 29:107-110.

18. Gray, S. M., Moyer, J. W., and Kennedy, G. G. 1988. Resistance in Cucumis melo to watermelon mosaic virus 2 correlated with reduced virus movement within leaves. Phytopathology 78:1043-1047.

19. Hulbert, S. H., Webb, C. A., Smith, S. M., and Sun, Q. 2001. Resistance gene complexes: Evolution and utilization. Annu. Rev. Phytopathol. 39:285-312 
20. Karchi, Z., Cohen, S., and Govers, A. 1975. Inheritance of resistance to cucumber mosaic virus in melons. Phytopathology 65:479-481.

21. Lecoq, H., Cohen, S., Pitrat, M., and Labonne, G. 1979. Resistance to cucumber mosaic virus transmission by aphids in Cucumis melo. Phytopathology 69:1223-1225.

22. Lecoq, H., and Pitrat, M. 1984. Strains of Zucchini yellow mosaic virus in muskmelon $(\mathrm{Cu}$ cumis melo L). J. Phytopathol. 111:165-173.

23. Lecoq, H., Wisler, G. C., and Pitrat, M. 1998. Cucurbit viruses: The classics and emerging. Pages 126-142 in: Cucurbitaceae '98, evaluation and enhancement of cucurbit germplasm. J. D. McCreight, ed. ASHS, Alexandria, VA.

24. Leroux, J. P., Quiot, J. B., Lecoq, H., and Pitrat, M. 1979. Mise en évidence et répartition dans le sud-est de la France d'un pathotype particulier du virus de la mosaïque du cocombre. Ann. Phytopathol. 11:431-438.

25. Lopez-Sesé, A. I., and Gómez-Guillamón, M. L. 2000. Resistance to cucurbit yellowing stunting disorder virus (CYSDV) in Cucumis melo L. HortScience 35:110-113.

26. Luis-Arteaga, M., Alvarez, J. M., AlonsoPrados, J. L., Bernal, J. J., Garcia-Arenal, F., Lavina, A., Batlle, A., and Moriones, E. 1998. Occurrence, distribution, and relative incidence of mosaic viruses infecting field-grown melon in Spain. Plant Dis. 82:979-982.

27. M.A.P.A. 2000. Anuario de Estadística Agroalimentaria 2000. Ministerio de Agricultura Pesca y Alimentación, Spain.

28. McCreight, J. D., Bohn, G. W., and Kishaba, A. N. 1992. 'Pedigree' P.I. 414723 melon. Cucurbit Genet. Coop. Rep. 15:51-52.

29. Nieto-Nafria, J. M., Díaz-González, T. E., and Mier-Durante, M. P. 1984. Catálogo de los pulgones (Homoptera: Aphidoidea) de España y de sus plantas hospedadoras. Universidad de Leon, Spain.

30. Pirone, T. P., and Harris, K. F. 1970. Nonpersistent transmission of plant viruses by aphids. Annu. Rev. Phytopathol. 15:55-73.

31. Pitrat, M. 1998. 1998 gene list for melon. Cucurbit Genet. Coop. Rep. 21:69-81.

32. Pitrat, M., and Lecoq, H. 1980. Inheritance of resistance to cucumber mosaic virus transmission by Aphis gossypii in Cucumis melo. Phytopathology 70:958-961.

33. Pitrat, M., and Lecoq, H. 1983. Two alleles for watermelon mosaic virus 1 resistance in muskmelon. Cucurbit Genet. Coop. Rep. 6:52-53.

34. Pitrat, M., and Lecoq, H. 1984. Inheritance of Zucchini yellow mosaic virus-resistance in Cucumis melo. Euphytica 33:57-61.

35. Provvidenti, R., and Gonsalves, D. 1982.
Resistance to papaya ringspot virus in $\mathrm{Cucu}$ mis metuliferus and its relationship to resistance to watermelon mosaic virus 1 . J. Hered. 73:239-240.

36. Raccah, B. 1986. Nonpersistent viruses Epidemiology and control. Adv. Virus Res. 31:387-429.

37. Risser, G., Pitrat, M., and Rode, J. C. 1977 Etude de la résistance du melon au virus de la mosaïque du concombre. Ann. Amélior. Plant. 27:509-522.

38. Soria, C., Díaz, J. A., Moriones, E., and Gómez-Guillamón, M. L. 2000. Resistance to Aphis gossypii and to virus transmission by this aphid in melon. Proceedings Cucurbitaceae 2000. M. Katzir and H. S. Paris, eds. Acta Hortic. (ISHS 2000) 510:305-312.

39. Soria, C., López-Sesé, A. I., and GómezGuillamón, M. L. 1999. Resistance of Cucumis melo L. against Bemisia tabaci Gennadius. Env. Entomol. 28:831-835.

40. Whitman, S., McCormick, S., and Baker, B. 1996. The $N$ gene to tobacco confers resistance to tobacco mosaic virus in transgenic tomato. Proc. Natl. Acad. Sci. USA 93:87768781 .

41. Zamir, D. 2001. Improving plant breeding with exotic genetic libraries. Nature Rev. Genet. 2:983-989. 